\title{
LA EXPERIENCIA DE LA TEMPORALIDAD EN CUATRO POEMAS DE ANTONIO MACHADO: PROPUESTA DE ANÁLISIS LINGÜÚSTICO
}

\author{
"Sed fugit interea, fugit irreparabile tempus, \\ singula dum capti circumvectamur amore." \\ Virgilio, Georgicas, Libro III, v. 284-285
}

"Tiempo es el paso de nuestra conciencia por la eternidad." Juan Ramón Jiménez, Tiempo

\section{Introducción}

"La poesía es - decía Mairena - el diálogo del hombre, de un hombre con su tiempo."

Antonio Machado

Uno de los grandes poetas españoles del siglo XX, Antonio Machado, era muy consciente de que todo artista está irrevocablemente arraigado en su tiempo y que sus creaciones no son otra cosa que la objetivación de su experiencia temporal. Esa sujeción del artista-poeta en el tiempo era para Machado una verdad axiomática ya que el "poeta del tiempo" crea su mundo poético con las ideas que no son categorías formales y lógicas sino son directas intuiciones del ser, de su propio existir. A través de estas intuiciones se convierte el tiempo en la temporalidad.

La verdadera raíz de la creación poética y del pensamiento machadiano es entonces el tiempo y a la profunda impresión de la temporalidad que emana de los versos del poeta, se añade un continuo esbozo teórico sobre el fundamento temporal de la poesía (en prólogos, poéticas, artículos y en los comentarios atribuidos a sus heterónimos Juan de Mairena, Abel Martín).

El interés y la preocupación de Machado por el tiempo no están fuera de lugar en una época caracterizada por el propósito de encontrar en el tiempo la fundamentalización de una nueva metafísica. Machado extiende a la esfera de la poesía aquello mismo que los pensadores desde Bergson hasta Heidegger vienen diciendo en el terreno de la filosofía. El tiempo machadiano es un tiempo cualitativo (López-Morillas, 1973: 256) que no se percibe sino intuitivamente (como la dureé de Bergson), ya que sólo la intuición (que es un ver) puede vislumbrar el flujo infinito de lo real. Una de las maneras de expresar la intuición temporal es precisamente el expresar un ver físico donde se ejemplifica que la función del poeta es eternizar un "ver temporal".

${ }^{1}$ Es ahí donde está la temporalidad machadiana según Dámaso Alonso (1962: 167) que resalta más el espacio que el tiempo en la poesía de Antonio Machado. Éste es, según Alonso, lo que vemos primero cuando pensamos en el arte de Machado, lo cual es obvio sobre todo en Soledades, Galerías y otros poemas, donde son los espacios soñados o mágicos aquello en que penetramos como lectores. El elemento "tiempo" está expresado por medio de una abertura espacial. 
Según algunos teóricos los conceptos principales de la filosofía de Heidegger condicionan la visión machadiana de la temporalidad como manifestación de la existencia; de la angustia como el sentido de la existencia y de la muerte como la realización de la existencia humana. Dámaso Alonso (1962: 175) destaca por otra parte, que lo más característico, continuo e intenso de la obra poética de Machado se produce antes de que él dé señales de una verdadera preocupación filosófica.

\section{Análisis lingüístico de un texto poético}

"Un lingüista que preste oídos sordos a la función poética del lenguaje y un estudioso de la literatura indiferente a los problemas lingüisticos son anacronismos flagrantes."

Jakobson (1975: 395)

La intención de este corto estudio es enfocar la temporalidad como la verdadera raíz de la creación poética y el pensamiento machadiano desde un punto de vista lingüístico, o más bien, desde un punto de vista estilístico-lingüístico puesto que nos van a interesar las características permantentes de las actuaciones lingüísticas del autor. Se seguirá en parte la propuesta de Briz (1997) y en parte la de Marcos Marín (1998) subrayando el mecanismo de las estructuras sintácticas, léxico-semánticas y pragmáticas que ponen en funcionamiento el entramado temporal y lo que supone este mecanismo para la interpretación del resultado comunicativo.

Entendemos por texto unidad comunicativa cuya coherencia ${ }^{2}$, la propiedad definidora de los textos, es un proceso inicialmente pragmático que arranca de la intención comunicativa del emisor y que se manifiesta en términos semánticos, en procesos sintácticos etc.

Todo texto verbal comunicativo implica la presencia de un sistema lingüístico que lo organiza. Coincidimos con Lamíquiz (1978) que ve el texto poético como un lugar donde se consigue una verdadera condensación de los poderes del lenguaje así que es en este tipo de texto donde el lingüista puede observar mejor la esencia comunicativa de las estructuras verbales.

El texto literario o poético, como entidad cerrada en su totalidad, es peculiar en cuanto al acto de comunicación. Ohmann (1987) pone de relieve que la fuerza ilocutiva de un poema es mimética, es decir, que una obra literaria imita (o refiere) intencionadamente una serie de actos de habla que de hecho no tienen otra forma de existencia. Nos parece útil también el concepto de Levin (1987) de la implícita oración dominante que es, según él, un postulado de todo texto poético y es la siguiente: Yo me imagino a mí mismo en, $y$ te invito a ti a concebir, un mundo en el que ... Dicha oración es conditio sine qua non de la comunicación poética, es la que expresa el tipo de fuerza ilocutiva que se supone que debe tener el poema.

Englobar sobre todo los niveles linguísticos de un texto literario no equivale por una parte a un escueto análisis gramatical de base oracional, ni siquiera, por otra, excluir tal

2 Además de ésta hay otros seis criterios que condicionan al texto como unidad: cohesión, intencionalidad, aceptabilidad, informatividad, situacionalidad e intertextualidad; véase Beaugrande, Dressler (1997). 
análisis por completo. Lo importante es integrar el análisis gramatical dentro del estudio del texto ya que así podemos observar las relaciones entre gramática y pragmática, las cuales ayudan a entender mejor el proceso de producción del texto y facilitan la interpretación del mismo. Es decir, el análisis textual de base lingüística parte de una observación del funcionamiento del sistema, pero al final debe dirigirse a la función literaria o poética.

\section{Elementos evocadores de la temporalidad}

En el constante diálogo poético que se realiza a través de las cosas Machado se desdobla para hablar con el tiempo, concretamente con "la mañana", "la noche" y "la tarde". Estas figuraciones con referencia a las partes en que fraccionamos el devenir inagotable del tiempo son los símbolos temporales fundamentales en la poesía machadiana de Soledades, galerías y otros poemas (1907) ${ }^{3}$.

La noche en la poesía de Machado se relaciona a veces con el proceso onírico, a veces se refiere a los casos de conciencia que se tornan oscuros y tormentosos a la luz del día, es decir que la noche machadiana puede introducimos al mundo tumultuoso de temores y puede convertirse en un consolador refugio que el hombre busca en los sueños. Marta Rodríguez (1998: 35) ve en esta dualidad la función simbólica bipolar de la noche machadiana.

La mañana de Machado es el porvenir hacia el cual el poeta normalmente mira con ilusión buscando esperanzas. Su elemento temporal antagónico es la tarde que es el verdadero eje temporal de $S G O P$ dado que los poemas en que el poeta habla con la tarde son los más característicos y abundantes. Las horas de la tarde son horas de melancolía, tristes, lentas, llenas de horror por las sombras que se avecinan por una parte y por otra también de esperanza que ha de traer el nuevo día.

Machado emplea a lo largo de su poesía diferentes procedimientos y recursos relativos al tiempo y a la temporalidad. Así, por ejemplo, son continuos los temas de las estaciones, días, horas, años; hay ciclos de poemas; es significante el empleo de verbos, adverbios, conjugaciones; son abundantes las anotaciones fugaces o descripciones minuciosas de los efectos destructivos del tiempo en las cosas, los seres, los árboles, el paisaje; a menudo se entrecruza el tiempo individual con el colectivo, el de la historia; son abundantes las figuras de estilo, la versificación, etc. (Sesé, 1978: 241). Cabe añadir también el empleo de imágenes-símbolos entre las cuales la imagen del agua, la de la fuente y la del camino figuran entre las predilectas del poeta.

La sustancia del tiempo es, según Machado, lo pasado de ahí que su mundo poético se construye normalmente en torno al recuerdo y, por eso, a menudo a través de las formas verbales con un eje de orientación al pasado. Zubiría (1969: 41) observa que Machado, en efecto, "parecía vivir en el pasado más que en el presente", que le caracterizaba un cierto aire de ausencia. Tal vez fue por eso que Rubén Darío lo retrató en tiempo pasado (con pretérito imperfecto, pretérito simple, condicional simple e imperfecto de subjuntivo) cuando escribió Oración por Antonio Machado en 1905. Los primeros tres versos

\footnotetext{
${ }^{3}$ Antonio Machado (2000), Soledades, Galerías y otros poemas (SGOP). Madrid: Cátedra. Se usa esta edición para los ejemplos citados.
} 
son: Misterioso y silencioso iba una y otra vez. / Su mirada era tan profunda / que apenas se podía ver. ${ }^{4}$

Para nuestro estudio de la temporalidad resulta útil la distinción entre varios momentos temporales en la expresión linguística. Según Hernández Alonso (1996) son los siguientes: el momento de la enunciación, en continuo devenir, al corresponderse con el presente del hablante; el momento del acontecimiento, momento en el que la acción o las acciones expresadas por el verbo tienen lugar; y la perspectiva, el enunciado del verbo desde su momento de la enuciación.

Enfocar la temporalidad de un texto poético desde el punto de vista lingüístico nos llevará sin duda al verbo que es "la más perfecta imagen, el más natural testigo y la primera consciencia del tiempo" (Criado de Val, 1992: 25). Cuando cualquier unidad léxicosemántica insertada en un contexto se categorice gramáticalmente como un verbo adquiere un contenido sintáctico temporal y dinámico. Y es un hecho que el "poeta del tiempo" prefería tejer la red temporal con el verbo y sus variantes morfológicas. Junto con éstas se estudiarán también otras categorías sintácticas de contenido deíctico.

Coincidimos con Miklič (1994) cuando advierte que el funcionamiento concreto de los tiempos verbales depende fundamentalmente de todo un conjunto de parámetros que constituyen el mecanismo de la expresión e interpretación temporal de cada texto.

En cuanto a la terminología entendemos por tiempo verbal "la categoría mediante la cual se expresa la orientación de una situación bien con respecto al punto central (el origen) bien con respecto a una referencia secundaria que, a su vez, está directa o indirectamente orientada respecto al origen".

Hablaremos de formas verbales en vez de tiempos del verbo para evitar la posible confusión y porque queremos que quede clara la distinción entre el tiempo físico, su correlato humano el tiempo psíquico, el tiempo cronológico y el tiempo lingüístico ${ }^{6}$. El estudio quiere acercarse a las relaciones de las cuatro entidades que condicionan la conceptualización del mundo del poeta y su expresión en el texto poético.

\section{Poemas analizados}

Nos vamos a centrar en 4 poemas de $S G O P$ porque es en este libro donde empieza el diálogo del poeta con el tiempo a través de las cosas, cantando las incidencias del personal tiempo humano. El período de la creación de este libro se considera como la etapa esencialmente romántica del poeta. Los temas principales son la soledad, la melancolía, la desilusión y el paso del tiempo marcados de un tono sentimental. La melancolía de las cosas muertas, gastadas, cubiertas por la pátina del tiempo, pero también la esperanza, las promesas de futuros acontecimientos en algunas composiciones de $S G O P$ expresan el sentimiento existencial, la preocupación por el ser en el tiempo.

\footnotetext{
${ }^{4}$ Rubén Dario: El canto errante (1907), en Obras poéticas completas. Ed. F. C. Sainz de Robles, Madrid, Aguilar, (1945: 812).

${ }^{5}$ Gramática descriptiva de la lengua española. Dirigida por Ignacio Bosque y Violeta Demonte, Madrid: Espasa (t. II: 2879).

${ }^{6}$ Siguiendo la línea trazada por Benveniste (1965).
} 


\section{XXXII}

Las ascuas de un crepúsculo morado detrás del negro cipresal humean ... En la glorieta en sombra está la fuente con su alado y desnudo Amor de piedra, que sueña mudo. En la marmórea taza reposa el agua muerta.

Este poema pertenece a la parte titulada $\mathrm{Del} \mathrm{Camino}^{7}$ y contiene lo fundamental de la temática de Machado: el crepúsculo, la fuente y el agua. Con sus seis versos anuncia la muerte a través del fluir del tiempo, la pérdida de las ilusiones.

Las unidades léxico-semánticas, a causa de su interrelación sémica, organizan una red temática dando al poema cierta tonalidad. En nuestro caso los campos semánticos en que se integran las palabras contribuyen a evocar una fuerte sensación melancólica, una atmósfera oscura, grave, casi fúnebre. Todo mundo poético crea su propio vocabulario, sus propios sinónimos y antónimos que se realizan en el léxico concreto de cada poema y en las palabras-clave que aparecen repetidamente en la obra de un poeta. La imagen del agua y de la fuente son palabras-clave machadianas. El agua es la conocida imagen de la vida pero en este poema es inmóvil, parada en el tiempo, simboliza la fugaz imagen de nuestra humana transitoriedad y su final, la muerte. La fuente machadiana es un símbolo del eterno fluir y del pasar irreversible; mas en este ejemplo se añade la soledad que nos invade, las ilusiones y esperanzas muertas. Normalmente el poeta dialoga con la fuente, pero aquí la fuente es de mármol, con agua parada y fría. El Amor, normalmente símbolo de la vida, se presenta en este poema como un amor mudo, muerto, un amor sumido en sueño.

En el poema prevalecen los sintagmas nominales cuyo efecto produce un ritmo lento, reposado y da sensación de estatismo. Con el contenido semántico de las ascuas, crepúsculo, cipresal, glorieta, sombra, piedra, taza, agua, la tensión aumenta y la pesadumbre del momento nos detiene en una profunda tristeza. La repetición de la significación sugestiva de las unidades léxico-semánticas, que contribuye al poema la densa gravedad, refleja el fluir del tiempo y la muerte. El tiempo se ha parado, el final del camino está por llegar.

Con el empleo de adjetivos, Machado pretende, según lo afirma él mismo, hacer de la palabra un medio expresivo de lo psíquico individual (valor cualitativo) de acuerdo con su pensar poético que es un pensar cualificador.

La posición del adjetivo en cualquier texto es de gran interés estilístico. Cuando prevalecen los adjetivos pospuestos (que es la posición normal), el estilo adquiere mayor sencillez y puede perder el brillo expresivo (Criado de $\mathrm{Val}, 1975$ ), ya que los adjetivos pospuestos delimitan la extensión y clasifican al sustantivo. Los epítetos desempeñan un

\footnotetext{
${ }^{7}$ Esta parte es considerada como la más lograda de $S G O P$ lo que demuestra también el hecho de que apenas había sido modificada en la edición corregida de 1907.
} 
papel importantísimo en la poesía por su carácter totalizante (Cohen, 1982) lo que quiere decir que envuelven sin posibilidad de oposición a la totalidad del sujeto a que se aplica.

En nuestro caso la distribución de los adjetivos postpuestos y antepuestos es equilibrada. Entre los adjetivos calificativos (morado, negro, alado, desnudo, de piedra, mudo, marmórea, muerta); cuatro son pospuestos y cuatro antepuestos. El empleo de estos adjetivos da a la tarde y al paisaje un aspecto estático, casi inmóvil. El adjetivo morado (v. 1) refuerza el color oscuro, negro, lo que provoca la sensación de un final pronto e imprescindible. En los versos 2, 4 y 5 los epítetos centran nuestra atención en el objeto mismo: en el verso 2 lo accidental pasa a ser lo existencial en negro cipresal. Puesto que la posición normal de adjetivos de colores es la pospuesta, la inversión provoca este destacado efecto expresivo. El epíteto en el verso 4 es redundante porque nos da una cualidad del objeto ya conocida: dios del amor es desnudo y alado. Pero es interesante después el contraste que provoca el empleo de mudo (v. 5), así la sensación de frialdad e inmovilidad es aún mayor y, de nuevo, se alude al paso de tiempo irremediable. Esta sensación aumenta con los versos 5 y 6 . Marmórea taza (v. 5) intensifica la inmovilidad y la impresión de muerte que culmina en las últimas dos palabras.

La sintaxis de la oración es típicamente machadiana: simple, prevalece la parataxis. Las formas verbales son 4 (humean, está, sueña, reposa) y todas en el presente absoluto. Tanto desde el punto de vista morfosintáctico como desde el semántico el efecto comunicativo es igual, se produce la impresión de un lento transcurrir, de un tiempo y espacio estáticos, parados. Con el primer verbo del poema al final del verso 2 se produce el descanso conclusivo absoluto (Criado de Val, 1975). El movimiento es mínimo. Eso se debe también al hecho de que el significado inherente de todos los verbos empleados es imperfectivo (humear, estar, soñar, reposar), lo que aún refuerza el estado, la detención en el momento. ${ }^{9} \mathrm{El}$ mencionado predominio de sintagmas nominales estratifica el poema, lo convierte en una memoria del hastío, del pasado, es como un viejo retrato en sepia que nos llena de nostalgia mientras nos invade una profunda tristeza. Es un poema que no tiene emisor ni destinatario explícito, parece que por ningún lado se divisa la visión del poeta. Como toda la lírica aparenta derivar hacia el polo del "yo", se produce un fenómeno de simbolización (Luján Atienza, 2000: 243); lo descrito pasa a entenderse como un estado de ánimo interior, y es como si se hubiera suprimido la parte literal de una comparación que relaciona lo interior con lo exterior.

8 "La visión de adjetivo [...], se capta en una lectura de interpretación linguística enunciativa no sólo por los adjetivos de lengua, como triste y sonoro, sino también por los adjetivos de discurso, expresados por un sustantivo precedido de un demarcador, como de metal, de huesos" Lamíquiz (1994: 80).

9 Fernández Ramírez (1986: 215) resalta el estado o la circunstancia permanente de las personas o las cosas que expresan los verbos imperfectivos en determinadas situaciones. 


\section{XLIII}

Era una mañana y abril sonreía.

Frente al horizonte dorado moría

la luna, muy blanca y opaca; tras ella, cual tenue ligera quimera, corría

la nube que apenas enturbia una estrella.

Como sonreía la rosa mañana

al sol del oriente abrí mi ventana;

y en mi triste alcoba penetró el oriente

en canto de alondras, en risa de fuente

y en suave perfume de flora temprana.

Fue una clara tarde de melancolía.

Abril sonreía. Yo abrí las ventanas

de mi casa al viento ... El viento traía

perfume de rosas, doblar de campanas ...

Doblar de campanas, lejanas, llorosas, suave de rosas aromado aliento ...

... ¿Dónde están los huertos floridos de rosas?

¿Qué dicen las dulces campanas al viento?

Pregunté a la tarde de abril que moría:

¿Al fin la alegría se acerca a mi casa?

La tarde de abril sonrió: La alegría

pasó por tu puerta - y luego, sombría:

Pasó por tu puerta. Dos veces no pasa.

El poema XIIII aparece de esta forma en la edición de SGOP en 1907 en la parte de Canciones. Se puede notar la división en dos partes que se definen por la doble referencia temporal: la mañana y la tarde de abril. La primera parte está formada por las dos primeras estrofas, es decir, del verso 1 al 5 y del 6 al 10. La mañana de abril se nos presenta mediante la descripción de la "muerte" de la luna y la presencia de una nube fugaz, pequeña e insignificante que apenas enturbia una estrella y es como tenue ligera quimera lo que adelanta simbólicamente el estremecimiento de esperanza que sacude al poeta. La rosa mañana le invita a participar en la eclosión de la naturaleza. En su triste alcoba, que representa el paisaje interior del poeta, entran el canto de alondras, la risa de fuentes y el perfume de flores primaverales. La segunda parte se refiere temporalmente a la tarde. El paisaje exterior sigue invitando al poeta, el abril sigue sonriendo, el perfume de rosas está anunciando la posible alegría. El poeta, embriagado por la llegada de la primavera, le pregunta a la tarde (es decir, se pregunta a sí mismo) si los floridos huertos de su ayer 
vuelven con la alegría, pero la tarde le desengaña. La primavera pasa sólo una vez por el corazón. El mundo sí se renueva, pero el espíritu del hombre no.

Merecen especial atención los sintagmas verbales que desempeñan aquí un importante papel en el entramado de relaciones temporales. Todas las formas personales del verbo (3) aparecen expresadas "in esse", es decir en modo indicativo. La distribución es la siguiente:

$1^{\text {a }}$ parte: era, sonreía, moría, corría, enturbia, sonreía, abrí, penetró;

$2^{a}$ parte: fue, sonreía, abrí, traía, están, dicen, pregunté, moría, se acerca, sonrió, pasó, pasó, pasa.

Pretérito imperfecto: $\quad 8$

Pretérito simple ${ }^{10}: \quad 8$

Presente absoluto: $\quad 5$

Pese a que la distribución entre los dos pasados es de 8:8, parece que el pretérito imperfecto desempeña el papel decisivo en cuanto a la ubicación en el tiempo y en el espacio del poema. Su significado básico témporo-aspectual es pasado imperfectivo. El valor temporal "pasado" se expresa ya sea como anterioridad respecto del presente del hablar o como simultaneidad o subsecuencia en relación con un punto de referencia situado en el pasado. Es una forma verbal con valor temporal del segundo plano, del nivel inactual (Coseriu, 1996: 97).

La coexistencia, como significación temporal predominante del imperfecto, influye en su uso estilístico que es de varia índole también por el hecho de que el pretérito imperfecto es un tiempo relativo. En la primera parte del poema predomina el pretérito imperfecto; la distribución en relación con otras formas verbales es de 5:3. Su función estilística es describir y crear un telón de fondo. Nos hace ver el pasado transportándonos a su propia época dando vida y actualidad a los hechos pasados. El poeta consigue hacer más vivas las representaciones mentales también con el inesperado presente, en este caso un tipo de presente histórico, en el verso 5: "la nube que apenas enturbia una estrella"; dando un salto del plano inactual o de la historia al plano actual o del discurso (siguiendo el concepto de Coseriu, 1996).

En la primera estrofa el poema nos hace esperar; al pintar una escena lánguida, nos detiene en "la escenografía", pero al mismo tiempo nos hace pendientes de lo que pasó.

Es notable el predominio de la rima en -ía en la primera estrofa (vv. 1,2,4), lo que no es extraño para la poesía de Machado. La preferencia por los tiempos imperfectos de las tres conjugaciones" se demuestra en la abundancia de las rimas en -ía y -aba a lo largo de sus poesías.

\footnotetext{
${ }^{10}$ Empleamos el término usado por Skubic (1969), "Pretérito simple y compuesto en los primeros textos castellanos." Actas del XI Congreso Internacional de Lingüistica y Filología Románica. Madrid: C.S.I.C. 1891-1901.

${ }^{11}$ En una ocasión Machado escribio: "Del pretérito imperfecto / brotó el romance en Castilla." (Machado, 1975: 159).
} 
En la segunda estrofa cambia la distribución temporal (sonreía, abrí, penetró). El imperfecto sonreía introduce la causa de las dos acciones puntuales que siguen (abrir la ventana, penetrar el oriente).

El presente absoluto es la forma conversacional, es decir del discurso y, en efecto, aparece en el diálogo del poeta con la tarde (vv. 17, 18, 20 y 23). Está muy claro el valor atemporal de las preguntas: “¿Dónde están los huertos floridos de rosas? / ¿Qué dicen las dulces campanas al viento? [...] ¿Al fin la alegría se acerca a mi casa?". Se trata de las inquietudes constantes y permanentes del poeta. El presente del verso 5 ya ha sido comentado más arriba.

En la parte de la tarde, hay un predominio del pretérito simple respecto a las otras dos formas verbales (presente absoluto y pretérito imperfecto). La distribución es la siguiente: fue, abrí, pregunté, sonrió, pasó, pasó; están, dicen, se acerca, pasa; sonreía, traía, moría (6:4:3).

El pretérito simple como forma absoluta del pasado expresa las acciones pasadas independientes de cualquier otra acción. En los versos 22 y 23 la fatalidad de lo pasado, de lo perdido se acentúa primero con el empleo del pretérito simple y aún más con la anáfora' ${ }^{12}$ : "pasó por tu puerta - Y luego, sombría: / Pasó por tu puerta. Dos veces no pasa".

Es de especial interés la diferencia entre los versos 1 y 11 con la que el poeta introduce la tarde respecto a la mañana: "Era una mañana y abril sonreía" y "Fue una clara tarde de melancolía".

Según algunos lingüistas ${ }^{13}$ la diferencia entre el empleo del pretérito imperfecto y el pretérito simple en los ejemplos de este tipo estriba sobre todo en el aspecto: fue indica el término de la acción, mientras que era no. Según ellos el contexto o la situación condiciona una u otra forma. Otros lingüistas ${ }^{14}$, en cambio, sostienen que se trata de una oposición cuyo eje no es exclusivamente el aspecto verbal, sino que son varios parámetros que la califican entre ellos la temporalidad verbal, categoría gramatical deíctica, en la cual se distinguen tres relaciones principales: anterioridad, simultaneidad y posterioridad con respecto al punto de referencia $u$ origen.

La distinción entre el tiempo y aspecto es uno de los problemas verbales de mayor interés. Esto se debe sin duda al hecho de que entre las categorías de tiempo y aspecto verbal no hay una exacta proporción, por tanto, la separación de sus respectivas zonas es bastante difícil. Siendo dos categorías estrechamente ligadas es de especial interés la naturaleza de su relación, o correlación siguiendo a Coseriu (1996: 85), la cual es origen de polémicas discusiones entre los lingüístas.

Interpretándolo desde el punto de vista discursivo o pragmático el pretérito simple narra y el pretérito imperfecto describe. En lo que se refiere al ejemplo del poema analizado sostenemos que la oposición es sobre todo aspectual y no temporal puesto que en los dos casos se trata de la anterioridad al momento de hablar. Coincidimos con Markič (1997)

\footnotetext{
12 "La anáfora consiste en la repetición de la misma palabra (o palabras) al principio de versos sucesivos." Luján Atienza (2000: 146).

${ }^{13}$ Esta posición la defienden entre otros Alarcos Llorach, Reyes, Silva Corvalán, Markič.

${ }^{14}$ Entre ellos Weinrich, Rojo, Lamíquiz, Gutiérrez Araus.
} 
que habla de las diferentes maneras con que el hablante contempla una acción. A través del pretérito imperfecto enfoca sólo la parte de la acción que está abierta, en transcurso, mientras que el pretérito simple presenta la acción en su totalidad, como cerrada, mostrando tanto el principio, el transcurso y el término de la acción.

Con la mañana y la tarde del poema analizado ocurre precisamente esto: están vistas desde perspectivas distintas, se trata de dos maneras de ver lo pasado. En era una mañana el poeta enfoca la situación en sí misma sin referirse al principio o al final de la acción. Se sitúa en un punto del pasado y mira a la mañana desde "dentro", está incluido en el transcurso de la acción percibiéndola desde allí. Con el imperfecto se siente todavía la posible esperanza de la alegría, el poeta deja las "puertas abiertas".

La perspectiva cambia con el pretérito simple; la descripción, el telón de fondo de era una mañana se hace narrativa en fue una clara tarde. El poeta lo enfoca desde el momento de hablar, es decir, desde fuera, transponiendo lo ocurrido a un tiempo y espacio alejados de la actualidad. La mañana trae esperanzas mientras que la tarde desengaña.

Una oposición parecida aparece en los versos 12 y 21 con sonreía y sonrió.

No estará de más mencionar la repetición del verbo morir en pretérito imperfecto. Moría, que aparece al final de los versos 2 y 19 ("Frente al horizonte dorado moría" y "Pregunté a la tarde de abril que moría"), provoca cierta imagen de estructura cerrada, de tiempo cíclico. Primero moría la luna y, al final del poema, moría la tarde. El verbo morir es ya de por sí un verbo cíclico, es decir, un verbo "que comporta un acontecimiento cíclico que se ejecuta en un intervalo ininterrumpido determinado y que encierra un proceso definido" (Coseriu, 1996: 141).

En lo que atañe a los adjetivos de lengua (Lamíquiz, 1994) es notable un fuerte predominio de los epítetos (entre los diecisiete adjetivos sólo tres son pospuestos) cuyo papel importante en la poesía comentábamos más arriba. El poeta centra nuestra atención en los objetos mismos (la rosa mañana, triste alcoba, suave perfume, ...). El epíteto clara es uno de los más empleados de Machado cuando se refiere a la tarde. Los así llamados adjetivos de discurso (Lamíquiz, 1994) complementan los epítetos por su abundancia (de alondras, de fuente, de melancolía, ...).

La sintaxis de la oración es bastante simple, predomina la parataxis sobre la hipotaxis, rasgo típico de la sintaxis emotiva. Entre las oraciones compuestas predominan las yuxtapuestas, hay una coordinada copulativa. Entre las subordinadas hay dos relativas y una adverbial causal.

La melancolía, tan típica para toda la poesía de $S G O P$, se manifiesta también a través de la referencia a cosas concretas que simbolizan la fugacidad del tiempo: la mañana y la tarde de abril, las lejanas y llorosas campanas, el viento que trae perfume de rosas. 
Este amor que quiere ser acaso pronto será; pero, ¿cuándo ha de volver lo que acaba de pasar?

Hoy dista mucho de ayer. ¡Ayer es Nunca jamás!

Se trata de la primera parte del poema LVII (Consejos ${ }^{15}$ ). Es un poemita de tono popular que recoge el tema conocido de Nevermore.

En lo que atañe a la temporalidad verbal este poema es interesante por su abundancia de las formas verbales. Éstas son tan frecuentes que girando en torno de sustantivos provocan una imagen del flujo del tiempo. Las formas quiere ser, será, ha de volver en la primera estrofa están todas vueltas hacia el porvenir, sus formas diferentes destacan la inseguridad, lo fugaz del futuro. Las dos perífrasis verbales aún refuerzan el juego temporal, el contraste entre lo que ha sido y lo que será. En ha de volver (v. 3) el valor temporal de futuro confluye con el matiz de la necesidad interna; se refuerza la fatalidad de lo que está por llegar. Con la aspectual terminativa acaba de pasar (v. 4) se expresa el final reciente uniendo la perfectividad y cercanía (temporal y lógica).

Los adverbios eran para Machado los elementos también aprovechables para dar temporalidad al verso. En los versos 5 y 6 aparece uno de sus recursos preferidos: el contraste entre hoy y ayer donde el ayer representa la principal raíz de su poesía. Esto se refuerza aún más con la anadiplosis "16. "Hoy dista mucho de ayer. /Ayer es Nunca jamás!"

Con esta figura sintáctica el poeta resalta el movimiento, la imagen del flujo del tiempo presente en todo el poema. ${ }^{17} \mathrm{El}$ ayer machadiano, que no volverá nunca jamás, encarna su mirada hacia los días vividos.

La sintaxis de la oración es más compleja, lo que normalmente requiere cierto dominio del discurso y sus enlaces lógicos. Su efecto es resaltar el movimiento y el entramado verbal.

Quizás quepa destacar el demostrativo este con el que empieza el poema. En su actividad enunciativa, el demostrativo desempeña doble función de presentador e indicador situacional. Su primordial valor comunicativo es el de la insistencia identificadora aparte del valor de proximidad en la que el poeta sitúa el amor. Este amor es una imagen temporal y no genérica; es la visión única del amor.

\footnotetext{
${ }_{16}^{15}$ La parte de SGOP que representa una poderosa veta de influencia popular.

16 "La anadiplosis es la repetición de la misma palabra al final de un verso y al principio del siguiente." Luján Atienza (2000).

${ }^{17}$ Según Bousoño la simple reiteración de un sonido, categoría gramatical, o de una palabra, dan sensación de movimiento. Véase: Carlos Bousoño (1970), Teoría de la expresión poética. Madrid: Gredos, 2 vols. $5^{\text {a }}$ edición
} 
Daba el reloj las doce ... y eran doce

golpes de azada en tierra ...

... ¡Mi hora! - grité - ... El silencio

me respondió: - No temas;

tú no verás caer la última gota

que en la clepsidra tiembla.

Dormirás muchas horas todavía

sobre la orilla vieja,

y encontrarás una mañana pura

amarrada tu barca a otra ribera.

Éste es, según Ribbans ${ }^{18}$, uno de los poemas machadianos más impresionantes de un presentimiento de la muerte. Lo específico del tema de la muerte en la poesía machadiana es que no hay una postura dada para siempre, sino que hay una sucesión de actitudes. En este poema se pone de relieve el hábito de esperarla que le hace presentirla siempre, el poeta adivina su inminente aparición. La conciencia de la presencia de la muerte es tan viva y aguda que provoca que las campanadas del reloj se conviertan en redoble funeral. El tiempo y la muerte parecen fundidos.

De acuerdo con el tema del poema Machado emplea con habilidad el cambio de la perspectiva temporal. El esquema de las formas verbales es el siguiente:

Pretérito imperfecto

Pretérito simple

Futuro simple

Presente absoluto

Imperativo negativo
2 (daba, eran)

2 (grité, respondió)

3 (verás, dormirás, encontrarás)

1 (tiembla)

1 (no temas)

La distribución entre los pasados frente al presente y futuro simple es 4:4. Esta alternancia (pasado, imperfecto, presente) constituye un recurso importante en la expresión de la temporalidad. Por una parte el poeta nos sitúa en el pasado narrativo (grité, respondió) enfocando las acciones desde fuera y creando un telón de fondo (daba el reloj, eran doce golpes) que provoca cierto efecto de tensión; por otra parte, con la insistencia del futuro absoluto (no verás, dormirás, encontrarás), nos traslada al porvenir que además se presenta como lejano. Normalmente la muerte es una presencia muda a la que se interroga sin jamás obtener respuesta alguna. Aquí el silencio le responde. Es significativo el oxímoro (el silencio me respondió) con el que aumenta la tensión, la inseguridad y la angustia de la existencia humana. El imperativo negativo del verso 4 (no temas) es a la vez autoritario y consolador.

${ }^{18}$ En Machado (2000: 116). 
El presente y el futuro hacen referencia a la situación comunicativa en la que el poeta, el yo del poema, participa directamente cuando el silencio le responde.

Entre las formas verbales prevalece el futuro simple o absoluto que "ocupa" la última parte del poema. Quizás la noción más característica del futuro es la inseguridad temporal y su tendencia modal que dan lugar a la multitud de sus usos. Fernández Ramírez (1986: 284) destaca la multitud de matices significativos y valores modales del futuro como tiempo verbal que exceden en mucho de la simple referencia a un momento futuro.

En los ejemplos del poema: tú no verás caer la última gota [...] Dormirás muchas horas todavía / y encontrarás una mañana pura se describe una situación desde el presente y se anticipa una acción que sabemos que sucederá por ser cíclica (Fernández Ramírez lo denomina futuro narrativo). Pero, por otra parte, el silencio quiere convencer al poeta de lo que pasará, por lo tanto se trata también de un futuro con matices apodícticos (Fernández Ramírez, 1986: 284).

La función apelativa desde el verso 5 hasta el final del poema se desarrolla en un plano doble: el tú del poema es tanto el poeta, como cualquier lector que se hace interlocutor del silencio.

Los sustantivos se integran en tres campos semánticos:

Tiempo: reloj, hora, gota, clepsidra, horas, mañana

Muerte: golpes, azada, tierra, silencio

Río/vida: orilla, barca, ribera

La odiosa presencia del reloj, que es símbolo de la angustia temporal humana, le marca a Machado el compás con que avanzan los pasos de la muerte. El poeta lo intensifica desarrollando reloj-doce golpes en clepsidra-última gota.

La orilla y la ribera aluden a la imagen del río que es la vida. El hombre viaja en una barca que al comparar con el agua no es nada y es arrastrada hacia el mar (en el poema no expreso explícitamente), ese término fatal en donde nuestra vida va a dar perdiéndose en él.

La adjetivación es escasa, pero por ello aún más significativa y puntúa con claridad la situación emocional de Machado ante el suceso de la muerte. Los dos adjetivos pospuestos en la orilla vieja y una mañana pura están en relación de contraste: el temporal viejo frente al intemporal puro. El epíteto en la última gota centra nuestra atención en el final imprescindible, pero el indefinido cuantificador en muchas horas lo desplaza a un futuro alejado.

Como se ha comentado más arriba, Machado se servía también de los adverbios para dar temporalidad al verso y situar las cosas en el tiempo. El adverbio todavía (v. 7) a primera vista no parece muy significativo pero es en él donde se centra la fatalidad temporal del poema; lo que no ha ocurrido todavía, está por ocurrir indispensablemente. ${ }^{19}$

\footnotetext{
${ }^{19}$ Otro de los ejemplos ilustrativos con "todavía": "Hoy es siempre todavia." Proverbios y cantares. La concentración de tres adverbios expresa la visión machadiana del tiempo como extensa continuidad, donde hoy es el presente en que el pasado todavía persiste, y donde está también el futuro, algo que todavía está por llegar.
} 


\section{Conclusión}

"Un poema es como un relato de viajero que procede fuera del espacio y del tiempo. Lo que ha visto es la realidad de algún otro mundo."

Según Machado el poeta debe eternizar el fluir del tiempo, debe crear una intemporalidad a través de lo temporal. Cada poema suyo es como un retazo de la vida de un viajero; toda la obra es una especie de sucesión de imágenes instantáneas a través de las cuales Machado nos va mostrando la realidad de la existencia humana, inmersa en un proceso temporal y desenvuelta en una demarcación espacial.

El lenguaje de Machado es simple por lo que se refiere a la sintaxis pero en el fondo muy complejo ya que esta misma sencillez formal es reflejo de un gran esfuerzo creador y una reflexión profunda que Machado ha debido de realizar. En realidad no le preocupa la palabra en sí, sino en cuanto materia fundamental del poema; la "palabra en el tiempo" machadiana es personal, clara y sencilla lo cual la convierte en la raíz de la impresión de naturalidad. Su misión es palpitar hondamente en el espíritu hundiéndose en lo que dice "el alma, si es que algo dice, con voz propia en respuesta animada al contacto del mun$d o " 20$.

La aproximación lingüística a la poesía de Antonio Machado demuestra que el poeta sabía entrelazar diferentes categorías sintácticas y utilizar la adecuada técnica discursiva de los deícticos temporales en operatividad comunicativa para formar el entramado temporal y dar a los poemas ese latido de organismos vivos, sometidos también al fluir de los instantes y sujetos a la muerte.

\section{Bibliografia}

Aranda, A. (1975): "La tarde en Soledades: personificación y adjetivación". En: La experiencia del tiempo en la poesía de Antonio Machado. Sevilla: Secretariado de publicaciones de la Universidad de Sevilla, 21-48.

Alonso, D. (1962): Cuatro poetas españoles (Garcilaso, Góngora, Maragall, Machado). Madrid: Gredos.

Beaugrande, R. de, Dressler, U. (1997): Introducción a la lingüistica del texto. Barcelona: Ariel Lingüística.

Benveniste, E. (1965): "El lenguaje y la experiencia humana". En: Problemas del lenguaje. Buenos Aires: Ed. Sudamericana, 3-12.

Briz, A. (1997): "Comentario lingüístico". En: El análisis textual. Salamanca: Ediciones Colegio de España, 77-130.

Cohen (1982): El lenguaje de la poesía. Teoría de la poeticidad. Madrid: Gredos.

Coseriu, E. (1996): El sistema verbal románico. México: Siglo XXI editores.

Criado de Val, M. (1975): Gramática española y comentario de textos. Madrid: Saeta.

${ }^{20}$ Así lo dice el mismo Antonio Machado en el prólogo a una de las ediciones de SGOP. 
Criado de Val, M. (1992): La imagen del tiempo: Verbo y relatividad. Madrid: Istmo.

Fernández Ramírez, S. (1986): "El verbo y la oración". En: Gramática española. Madrid: Arco/Libros.

Gullón, R. (1949): “Lenguaje, humanismo y tiempo en Antonio Machado". En: Cuadernos Hispanoamericanos. Madrid, sept-dic. 1949, 567-581.

Gutiérrez Araus, M. L. (1995): Formas temporales del pasado en indicativo. Madrid: Arco/Libros. Hernández Alonso (1996): Gramática funcional del español. Madrid: Gredos, 334-336 y $406-422$.

Jakobson R. (1975): Ensayos de lingüística general. Barcelona: Seix Barral.

Lamíquiz, V. (1994): El enunciado textual. Análisis lingüístico del discurso. Barcelona: Ariel Lingüística.

Levin, S. R. (1974): Estructuras lingüísticas en la poesia. Madrid: Cátedra.

Levin, S. R. (1987): "Consideraciones sobre qué tipo de acto de habla es un poema". En: Pragmática de la comunicación literaria. Madrid: Arco/Libros, 59-82.

López-Morillas, J. (1973): "Antonio Machado y la interpretación temporal de la Poesía". En: Antonio Machado. Edición de R.Gullón y A.W. Phillips, Madrid: Taurus Ediciones, 251-266.

Luján Atienza, Á. L. (2000): Cómo se comenta un poema. Madrid: Editorial Síntesis.

Machado, A. (1936/1993): Juan de Mairena. 2 t. Antonio Fernández Ferre (ed.). Madrid: Cátedra.

Machado, A. (1972/1987): Los complementarios. Manuel Álvar (ed.). Madrid: Cátedra.

Machado, A. (1907/2000): Soledades, Galerías y otros poemas. Geoffrey Ribbans (ed.). Madrid: Cátedra.

Marcos Marín F. (1998): El comentario lingüistico. Madrid: Cátedra.

Markič, J. (1997): Aspektualne vrednosti v sodobni ameriški španščini v delih kolumbijskega pisatelja G. Garcíe Márqueza. Tesis doctoral. Ljubljana: Univerza v Ljubljani, Filozofska fakulteta, Oddelek za romanske jezike in književnosti.

Miklič, T. (1994): “Besedilni mehanizmi učasovljanja zunajjezikovnih situacij”. En: Uporabno jezikoslovje 2 (2). Ljubljana, 80-99.

Ohmann, R. (1987): "Los actos del habla y la definición de literatura." En: Pragmática de la comunicación literaria. Madrid: Arco/Libros, 11-34.

Reyes, G. (1990): "Tiempo, modo, aspecto e intertextualidad". En: R.S.E.L., enero-junio 1990, año 20 , fasc. 1 .

Rodríguez, M. (1998): El intimismo en Antonio Machado. Madrid: Visor libros.

Romero, A. (1975): Semántica y simbolismo en el poema XIII de "Del camino". En: Ángeles, J., (ed.), La experiencia del tiempo en la poesía de Antonio Machado. Sevilla: Secretariado de publicaciones de la Universidad de Sevilla, 133-143.

Ruíz Ramón, F. (1977): "Algunas aproximaciones al problematismo del tema de la muerte en la poesía de Antonio Machado". En: Estudios sobre Antonio Machado. Barcelona: Editorial Ariel, 231-257. 
Sesé, B. (1978): Claves de Antonio Machado. Madrid: Espasa Calpe.

Torre, E. (1975): "El campo semántico de la duración existencial en las Soledades". En: La experiencia del tiempo en la poesía de Antonio Machado. Sevilla: Secretariado de publicaciones de la Universidad de Sevilla, 85-99.

Zubiría, R. de (1969): La poesía de Antonio Machado. Madrid: Gredos.

\section{IZKUŠNJA ČASOVNOSTI V ŠTIRIH PESMIH ANTONIA MACHADA: PREDLOG JEZIKOVNE ANALIZE}

Članek je oris jezikovne analize literarnega besedila s posebnim poudarkom na izražanju časovnosti v štirih pesmih Antonia Machada iz zbirke Soledades, Galerías y otros poemas. Avtorica članka najprej obravnava časovnost kot dejansko jedro Machadove poezije s filozofsko-literarnega vidika, nato pa problematiko izražanja časovnosti v literarnih besedilih osvetli $z$ jezikoslovno-pragmatičnega zornega kota. Osredotoči se na tiste skladenjske, leksikalno-semantične in pragmatične strukture, ki so bistvene za vzpostavitev časovne mreže odnosov v literarnem besedilu. Poudarek je na glagolu kot sintaktični kategoriji, ki primarno izraža časovnost, analizira pa se tudi vloga drugih deiktičnih struktur.

Lingvistični pristop $\mathrm{k}$ Machadovi poeziji kaže na spretno prepletanje jezikovnih struktur ter raznolikih diskurzivnih tehnik, $s$ katerimi si je Machado prizadeval v praksi uresničiti koncept poezije kot pesnikovega dialoga s časom. Machadova »beseda v času« je osebna, jasna in preprosta; kot taka je temeljna snov njegove poezije, nekakšnega zaporedja trenutnih podob, $v$ katerih se zrcali realna človeška eksistenca, vpeta v prostor in čas. 